\title{
Evaluasi Tata Kelola Teknologi Informasi Menggunakan Framework Simcobit, Studi Kasus pada Sekolah Tinggi Ilmu Kesehatan Bina Husada Palembang
}

\author{
Rendi Septriadi $^{1)}$, Firdaus $^{2)}$, Widya Cholil ${ }^{3)}$ \\ ${ }^{12) 3)}$ Program Pascasarjana Universitas Bina Darma \\ Jl. A. Yani No.12, Palembang 30624 \\ Email : $\underline{\text { rsseptriadi@yahoo.com }}{ }^{1)}, \underline{\text { firdaus.dr@binadarma.ac.id }}{ }^{2)}, \underline{\text { widya@binadarma.ac.id }}^{3)}$
}

\begin{abstract}
ABSTRACK
The Information technology governance that is mostly used is COBIT 5 . in order to simply the process domain mapping SIMCOBIT was used as a framework. it was used to find out the information technology governance at Sekolah Tinggi Ilmu Kesehatan Bina Husada Palembang and to give the improvement of the information technology governance itself. This study was quantitative descriptive evaluation research. In this study questionnaries were used in order to measure the capability level. Based on the result it can be concluded that STIK Bina Husada Palembang was at the level 1 capability (Performed process)for TIPO01 process managing the IT Management framework, TIPO05 Managing program and project, and TIPO07 managing operations and achieving the process objective with achieved scale, and organizations in both processes.
\end{abstract}

Keywords : An Evaluation of Governance,SIMCOBIT, TIPO01,TIPO05,TIPO07

\begin{abstract}
ABSTRAK
Tata kelola teknologi informasi yang banyak digunakan yaitu COBIT 5. Namun untuk menyederhanakan dalam pemetaan domain proses digunakanlah sebuah framework yang disebut SIMCOBIT, yang akan mengetahui kondisi tata kelola teknologi informasi di Sekolah Tinggi Ilmu Kesehatan Bina Husada Palembang dan memberikan perbaikan tata kelola teknologi inforasi.penelitian ini adalah peneilitian evaluasi deskriptif kuantitatif. Hasil pengukuran tingkat kapabilitas melalui metode kuesioner. Dapat disimpulkan bahwa STIK Bina Husada Palembang berada pada tingkat kapabilitas level 1 (performed process) untuk proses TIPO01 Mengelola Kerangka Kerja dan Manajemen, TIPO05 Mengelola Program dan Project, dan TIPO07 Mengelola Operasi dapat mencapai tujuan prosesnya dengan skala Partially Achieved, serta organisasi akan meningkatkan nilai Capability Level menjadi naik 1 level dari hasil yang telah dicapai.
\end{abstract}

Kata kunci : Evaluasi Tata Kelola, SIMCOBIT, TIPO01,TIPO05,TIPO07 


\section{Pendahuluan}

Teknologi Informasi menjadi salah satu hal yang banyak diadopsi oleh hampir seluruh organisasi, baik organisasi yang menghasilkan laba ataupun nirlaba baik perusahaan swasta atau instansi pemerintahan. Teknologi informasi dipercaya dapat meningkatkan efisiensi dan efektifitas pada sebuah organisasi untuk mencapi tujuannya. Beberapa Sekolah Tinggi Ilmu Kesehatan di palembang memiliki fungsi sebagai pengelola administrasi dan manajemen tak terkecuali mengadopsi teknologi informasi untuk mencapai tujuannya. Sekolah Tinggi Ilmu Kesehatan Bina Husada palembang adalah salah satu institusi atau sekolah tinggi yang menggunakan Teknologi Informasi untuk menunjang pelayanan akademi.

Teknologi Informasi adalah investasi asset yang sangat berharga kedudukannya dengan asset-asset yang lain, sangat disayangkan sekali apabila investasi aset yang bisa dikategorikan memakan biaya yang tidak sedikit ini tidak dimanfaatkan secara optimal. Evaluasi bertujuan untuk menilai, memonitor, dan memastikan bahwa sistem informasi sekolah dapat mengelola integritas data dengan baik dan mampu beroperasi secara efektif sesuai dengan tujuan sekolah dan tujuan Teknologi Informasi sekolah.berdasarkan latar belakang yang telah dijelaskan, peneliti berkeinginan mengajukan judul penelitian "Evaluasi Tata Kelola Teknologi Informasi Menggunakan Framework Simcobit, Studi Kasus Pada Sekolah Tinggi Ilmu Kesehatan Bina Husada Palembang".

Dari penjelasan sebelumnya maka identifikasi rumusan masalah yaitu "Bagaimana kondisi tata kelola teknologi informasi saat ini yang sedang berjalan di Sekolah Tinggi Ilmu Kesehatan Bina Husada, apakah sudah di manfaatkan secara optimal oleh pengguna teknologi informasi tersebut? Dan Rekomendasi perbaikan seperti apa yang dilakukan terkait tata kelola teknologi informasi di Sekolah Tinggi Ilmu Kesehatan di kota Palembang dan sampai tahap yang diharapkan?" .Agar penelitian ini lebih terarah dan tidak menyimpang dari permasalahan yang ada, maka diperlukan adanya batasan masalah. Penelitian fokus pada tata kelola teknologi informasi menggunakan Framework SIMCOBIT yang merupakan pengembangan model dari COBIT 5 dengan domain TIPO01 (Mengelola kerangka kerja IT Manajemen), TIPO05 (Mengelola Program dan Project) dan domain TIPO07 (Mengelola Operasi),

Adapun tujuan peneltian ini Mengetahui kondisi tata kelola teknologi informasi di Sekolah Tinggi Ilmu Kesehatan Bina Husada palembangdan memastikan penggunaan teknologi Informasi tersebut telah digunakan secara maksimal seperti yang diharapkan dan memberikan rekomendasi perbaikan.

\section{A. Metodologi Penelitian}

\section{Konsep Model Penelitian}

Penelitian ini adalah penelitian evaluasi deskriptif kuantitatif. Penelitian evaluasi merupakan bagian dari pembuat keputusan, yaitu membandingkan suatu kejadian, Penelitian menggunakan metode survei, dimana dilakukan pengambilan data dari sampel populasi mahasiswa dan dosen STIK Bina Husada Palembang menggunakan kuisioner sebagai alat pengumpulan data primer dengan penyebaran kuesioner kepada 29 orang responden Data sekunder yang merupakan kumpulan data yang sebelumnya telah dikumpulkan dari dokumen dan studi pustaka,

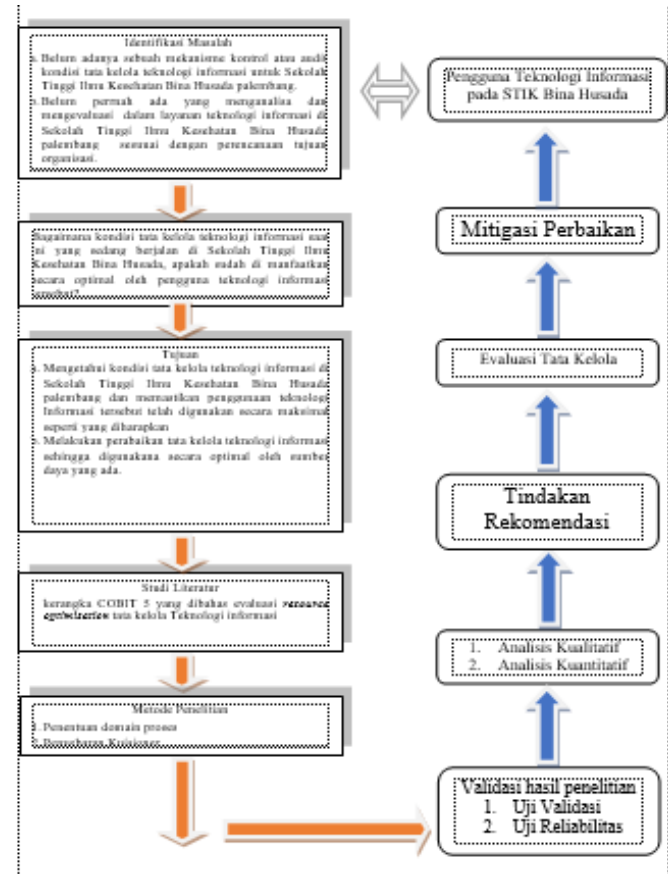

Gambar 1. Desain Penelitian

2. Tinjauan Pustaka

Menurut Wibowo (2007) Tata kelola Teknologi Informasi (IT governance) adalah kewenangan dan struktur pembuatan keputusan dari pimpinan dan manajer organisasi untuk mengoptimasi dan mengontrol penggunaan sumber daya teknologi informasi, dimulai dari perencanaan, implementasi dan monitoring atau evaluasi untuk mencapai tujuan organisai dengan menggunakan mekanismme tertentu.

Tata kelola teknologi informasi merupakan salah satu aspek penting dari tata kelola perusahaan secara keseluruhan. Pengolahan teknologi informasi yang baik akan menjamin efisiensi dan pencapaian kualitas layanan yang baik bagi tujuan bisnis perusahaan.

Dalam melakukan evaluasi tata kelola teknologi informasi dibutuhkan panduan standard. COBIT 5 yang memungkinkan TI untuk dikelola dan diatur dalam cara yang lebih menyeluruh untuk seluruh lingkup perusahaan meliputi lingkup bisnis dan lingkup area fungsional TI, dengan mempertimbangkan kepentingan para stakeholder internal dan eksternal yang berhubungan dengan TI. Adapun yang menjadi pokok pembahasan adalah mengoptimalkan penggunaan framework COBIT 5 dalam proses audit TI pada suatu organisasi. Selama ini COBIT 5 sudah sangat dikenal sebagai best practice yang terbaik untuk IT Governance dan IT Audit Framework.melihat adanya permasalahan 
penggunaan framework tersebut belum begitu optimal, efisien dan efektif bagi para user atau auditor dalam proses audit atau internal control pada sebuah organiasasi. Banyak faktor yang menjadi perhatian peneliti sebagai variabel penentu permasalahan tersebut, anatra lain kendala bahasa, pemahaman dan budaya. Berdasarkan hal tersebut, maka SIMCOBIT merupakan sebuah proyek yang dilakukan sebagai objek penelitian disertasi Dr.Widya Cholil,S.Kom.,M.TI. adalah sebuah model Audit TI yang lebih mudah dipahami, dan digunakan oleh user serta sesuai dengan kondisi masingmasing organisasi. Dalam proses SIMCOBIT terdapat 3 (tiga) Domain dan 23 (Dua puluh tiga )

Beberapa penelitian yang dianggap dapat menjadi acuan dalam penelitian ini adalah sebagai berikut :

a. Devie Firmansyah (2015) dengan judul "Pengukuran Kapabilitas Pengelolaan Sistem Informasi Sub Domain Deliver, Service,Support 01 Menggunakan Framework Cobit 5".

Pemanfaatan Teknologi Informasi (TI) untuk mendukung keberadaan sistem informasi menjadi sangat penting dalam menghadapi persaingan dan peluang di dunia pendidikan khususnya di perguruan tinggi. Model pengelolaan TI dan model audit sistem informasi perguruan tinggi yang banyak digunakan yaitu COBIT 5 (Control Objectives for Information dan related Technology). COBIT adalah standar pengendalian yang umum terhadap teknologi informasi, dengan memberikan Framework dan Control terhadap teknologi informasi yang dapat diterapkan dan diterima secara Internasional. Hasil pengukuran tingkat kapabilitas Politeknik Komputer Niaga LPKIA melalui metode kuesioner proses DSS01 (Mengelola Operasi) didapatkan tingkat kapabilitas sekarang berada dilevel 1 (Performed process) dimana Proses diimplementasikan dan mencapai tujuan prosesnya, dengan skala kapabilitas "Partially Achieved".

b. Ignatius Adrian Mastan (2010) Dengan judul Audit Sistem Informasi Perpustakaan STIKOM Surabaya menggunakan standar COBIT.

Perpustakaan STIKOM Surabaya adalah departemen di STIKOM Surabaya yang menangani layanan siap pakai misalnya dalam bentuk buku, majalah, perangkat lunak dan juga karya ilmiah. Dalam perkembangannya perpustakaan STIKOM Surabaya telah menggunakan aplikasi sistem informasi yang terintegrasi untuk kegiatan operasionalnya. Untuk penggunaan sistem informasi, beberapa aplikasi yang ada tidak digunakan secara maksimal. Maka dari itu diperlukan audit sistem informasi untuk mengenalnya. Dalam penelitian ini COBIT mengunakan 4.0 sebagai standar dalam pelaksanaan auditnya, karena COBIT adalah standar audit yang dapat digunakan untuk mengelola perencanaan teknologi informasi. Penerapan COBIT dilakukan dengan menggunakan wawancara dan kuesioner yang kemudian data diolah untuk mengetahui model kematangan dan dianalisis dengan SWOT. Dari adalah hasil yang diperoleh rekomendasi dan temuan untuk perbaikan sistem informasi Perpustakaan STIKOM

\section{Hasil dan Pembahasan}

\section{A. Penilaian kapabilitas proses}

Berdasarkan hasil kuesioner pada STIK Bina Husada Palembang yang di berikan kepada pengguna sistem informasi di lingkungan STIK Bina Husada palembang. Maka dilakukan penilaian Kapabilitas proses untuk mengetahui tingkat kapabilitas proses penerapan tatakelola Teknologi Informasi yang dapat dilihat pada tabel.

Dalam penilaian kapabilitas proses digunakan atribut proses yang disebut base practice, yang dipakai untuk melihat pencapaian tujuan proses yang harus dilakukan oleh organisasi dan work product untuk melihat hasil dari penerapan base practice tersebut. Berdasarkan hasil kuesioner yang telah didistribusikan ke responden dapat dihitung tingkat kapabilitas untuk setiap proses base practice dan work product yang dihasilkan . isian kuesioner berupa jawaban yang diinterpretasikan dengan "Ya" bernilai 1 dan "Tidak" bernilai 0. Dari perhitungan jawaban kuesioner tersebut dapat dilihat dari tabel berikut:

Tabel 1. Rekapitulasi Jawaban Kuesioner Atribut Base Practice

\begin{tabular}{|c|c|c|c|c|c|c|}
\hline \multirow{2}{*}{ No } & \multirow{2}{*}{ Kode } & \multirow{2}{*}{ Proses } & \multicolumn{4}{|c|}{ Base Practice } \\
\hline & & & $\mathrm{Ya}$ & Tidak & Jumlah & $\%$ \\
\hline 1 & TIP001 & $\begin{array}{l}\text { Mengelola kerangka kerja IT } \\
\text { manajemen }\end{array}$ & 80 & 65 & 145 & 55 \\
\hline 2 & TIP005 & $\begin{array}{l}\text { Mengelola program dan } \\
\text { project }\end{array}$ & 33 & 25 & 58 & 57 \\
\hline 3 & TIP007 & Mengelola Operasi & 74 & 71 & 145 & 51 \\
\hline
\end{tabular}

Tabel 2. Rekapitulasi Jawaban Kuesioner Atribut Work Product

\begin{tabular}{|c|c|c|c|c|c|c|}
\hline \multirow{2}{*}{ No } & \multirow{2}{*}{ Kode } & \multirow{2}{*}{ Proses } & \multicolumn{4}{|c|}{ Work Product } \\
\hline & & & $\mathrm{Ya}$ & Tidak & Jumlah & $\%$ \\
\hline 1 & TIP001 & $\begin{array}{l}\text { Mengelola kerangka kerja IT } \\
\text { manajemen }\end{array}$ & 70 & 75 & 145 & 48 \\
\hline 2 & TIP005 & $\begin{array}{l}\text { Mengelola program dan } \\
\text { project }\end{array}$ & 29 & 29 & 58 & 50 \\
\hline 3 & TIP007 & Mengelola Operasi & 75 & 70 & 145 & 52 \\
\hline
\end{tabular}

Tabel 3. Skala Rating Kapabilitas

\begin{tabular}{|ccccccccccc|}
\hline \multirow{2}{*}{ No } & \multirow{4}{*}{ Kode } & \multicolumn{3}{c|}{ Base Practice } & \multicolumn{3}{c|}{ Work Product } & skala & Rating \\
& & & Ya & Jumlah & $\%$ & Ya & Jumlah & $\%$ & $\%$ & \\
\hline & & & & & & & & & \\
1 & TIP001 & 80 & 145 & 55 & 75 & 145 & 48 & 52 & L \\
\hline 2 & TIP005 & 33 & 58 & 57 & 29 & 58 & 50 & 53 & L \\
\hline 3 & TIP007 & 74 & 145 & 51 & 75 & 145 & 52 & 51 & L \\
\hline
\end{tabular}

dapat dilihat penentuan rating dari skala yang di dapat dalam bentuk persentase, dinilai berdasarkan skala penilian standar dari ISO/IEC 15504-2 (2003,p.11), yakni 
- $\mathrm{N}-$ Not Achieved : 0-15\% achievement

- P - Partially achieved : $>15 \%-50 \%$ achievement

- L - Largely achieved : $>50 \%-85 \%$ achievement

- F - Fully achieved : > $85 \%-100 \%$ achievement

Dapat dikatakan bahwa skala pada proses TIPO01 (Mengelola kerangka kerja IT manajemen) berada di skala $52 \%$ berada di range Largely achieved (L). Proses TIPO05 (Mengelola program dan project) mendapatkan hasil dengan skala 53\% berada di Largely achieved (L). Begitu juga pada proses TIPO07 (Mengelola Operasi) skala yang di dapatkan $51 \%$ berada di Largely achieved (L). Jadi dari rata rata proses yang dinilai kapabilitas proses pada tatakelola Teknologi Informasi pada STIK Bina Husada berada diskala Largely achieve (L) yang berarti Proses dijalankan, Proses yang diimplementasikan berhasil mencapai tujuannya.

Setelah mendapatkan skala kapabilitas dari penilaian tatakelola yang telah di lakukan maka untuk menentrukan berada di level mana kriteria tingkat kapabilitas prosesnya dapat dilihat dari tabel berikut :

Tabel 4. Skala Rating Kapabilitas

\begin{tabular}{|l|l|l|l|l|l|l|l|l|l|}
\hline \multirow{2}{*}{$\begin{array}{l}\text { Level } \\
\text { kapabilitas }\end{array}$} & 1.1 & $\begin{array}{l}\text { PA } \\
2.1\end{array}$ & $\begin{array}{l}\text { PA } \\
2.2\end{array}$ & $\begin{array}{l}\text { PA } \\
3.1\end{array}$ & $\begin{array}{l}\text { PA } \\
3.2\end{array}$ & $\begin{array}{l}\text { PA } \\
4.1\end{array}$ & $\begin{array}{l}\text { PA } \\
4.2\end{array}$ & $\begin{array}{l}\text { PA } \\
5.1\end{array}$ & $\begin{array}{l}\text { PA } \\
5.2\end{array}$ \\
\hline $\begin{array}{l}\text { Level 0 } \\
\text { incomplete }\end{array}$ & N/P & & & & & & & & \\
\hline $\begin{array}{l}\text { level 1 } \\
\text { performed }\end{array}$ & L/F & & & & & & & & \\
\hline $\begin{array}{l}\text { level 2 } \\
\text { managed }\end{array}$ & F & L/F & L/F & & & & & & \\
\hline $\begin{array}{l}\text { level 3 } \\
\text { established }\end{array}$ & F & F & F & L/F & L/F & & & & \\
\hline $\begin{array}{l}\text { level 4 } \\
\text { predictable }\end{array}$ & F & F & F & F & F & L/F & L/F & & \\
\hline $\begin{array}{l}\text { level 5 } \\
\text { optimizing }\end{array}$ & F & F & F & F & F & F & F & L/F & L/F \\
\hline
\end{tabular}

Dari tabel diatas dapat dilihat bahwa untuk mencapai level 1 performed yang berarti bahwa Proses yang diimplementasikan berhasil mencapai tujuannya, skala yang harus dicapai dari penerapan tatakelola Teknologi Informasi bernilai F (Fully achieved : >85\% - 100\% achievement) atau L (Largely achieved : >50\% - 85\% achievement). Oleh karena hasil dari perhitungan kapabilitas seperti yang ditampilkan dalam tabel 4.9 terlihat bahwa skala yang dicapai adalah L (Largely achieved : >50\% - 85\% achievement) dapat dikatakan bahwa organisasi beradea pada kapabilitas level 1 Performed yang berarti Proses diimplementasikan untuk mencapai tujuannya. Pada tingkatan ini, terdapat bukti penerapan teknologi informasi namun masih ada proses yang belum terdokkumentasikan dengan baik atau bahkan tidak ada bukti dokumentasi.

\section{B. Analisis Kesenjangan}

Berdasarkan hasil analisa tingkat kapabiltas tatakelola Teknologi Informasi pada proses pengelolaan masalah di STIK Bina Husada Palembang saat ini (as-is) maka dapat diketahui bahwa tingkat kapabilitas yang di tetapkan sebagai acuan (to-be) IT Governance pada mengelola operasi tersebut didefenisikan berada pada level 1 (Performed) yang berarti proses diimplementasikan untuk mencapai tujuannya. Pada tingkatan ini, terdapat bukti penerapan teknologi informasi namun masih ada proses yang belum terdokumentasikan dengan baik atau bahkan tidak ada bukti dokumentasi. Sementara itu untuk mencapai kelevel selanjutnya atau level 2 (managed process), maka STIK Bina Husada Palembang harus memenuhi syarat dan memiliki dokumen-dokumen sebagai berikut;

1. SOP layanan dan pengembangan TI

2. Catatan backup data

3. Perencanaan audit independen

4. Prosedur monitoriing infrastruktur TI

5. Laporan monitoring infrastruktur TI

6. Dokumen kebijakan tentang keadaan lingkungan sekitar fasilitas TI

7. Laporan penilaian fasilitas TI

8. Laporan tentang keamanan fasilitas TI

Berdasarkan pengamatan, wawancara dan dari hasil kuesioner STIK Bina Husada Palembang berada pada level 1 dan akan menuju pada level 2 (Managed Process) .oleh karena itu akan terjadi jarak antara kondisi saat ini dan ekspetasi yang diharapkan. Dengan demikain harus dilakukan analisa untuk menutupi gap antara Current Capability dengan Expected Capability tersebut. Grafik dibawah ini akan memberikan penjelasan gap antara kedua Capability level untuk setiap domain yang diambil.

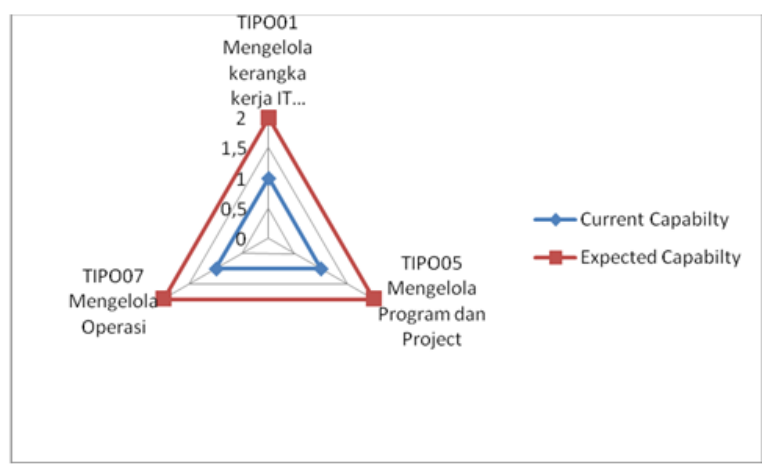

Gambar 2. Grafik Gap Current dengan Expected

Penerapan sistem informasi di STIK Bina Husada Palembang harus dapat menutupi gap Capability level ini. Sehingga seluruh sumber daya yang ada mampu mendukung selurh proses bisnis penerpan sistem inforamsi dalam mencapai tujuan yang telah di tetapkan dalam visi dan misi Organisasi. Gap yang ada dapat ditutupi dengan melakukan kegiuatan sesuai standarisasi pada Capability level.

Selanjutnya penerpan sistem informasi yang diharapkan dapat mencapai kondisi pada Capability level 2 dengan sesuai standar COBIT. Kondisi yang ingin dicapai pada proses adalah sebagai berikut :

1. Pelatihan penggunaan sistem informasi kepada pengguna secara formal dengan instruktur yang ahli dibidangnya. 
2. Pemeliharaan sistem informasi secara menyeluruh dilakukan dengan prosedur yang baku, untuk mempertahankan kualitas layanan dan keamanannya.

3. Fasilitas jaringan dan internet mendukung sistem informasi dan memiliki kecepatan yang memadai.

4. User manual dan prosedur pengoperasian sistem informasi terdokumentasi dan di informasikan dengan jelas

5. Institusi seluruhnya dapat menfaatkan informasi dari sistem informasi yang ada Pengelola/manajeman selalu menjaga sistem informasidapat digunakan user secara keseluruhan dengan baik

\section{Kesimpulan}

Berdasarkan dari hasil penelitian dan analisis yang sudah dilakukan pada tata kelola Teknologi Informasi di STIK Bina Husada Palembang maka dapat diambil kesimpulan sebagai berikut :

1. Evaluasi dilakukan menggunakan framework SIMCOBIT yang merupakan pengembangan model dari COBIT 5 domain TIPO01 (Mengelola kerangka kerja IT Manajemen), TIPO05 (Mengeloal Program dan Project) dan domain TIPO07 (Mengelola Operasi). Evaluasi dilakukan dengan melakukan wawancara, observasi dan penyebaran kuesioner kepada 29 orang responden yang kemudian hasilnya divalidasi.

2. Tingkat kemampuan atau Capability Level dari hasil evaluasi tata kelola sistem keamanan teknologi informasi di STIK Bina Husada Palembang adalah sebagai berikut :

a. Tingkat kemampuan atau Capability Level domain TIPO01 Mengelola kerangka kerja IT Manajemen berada pada level 1 yaitu performed process. Hasil tersebut menunjukan bahwa proses yang terimplementasi telah mencapai tujuan prosesnya, dilakukan tetapi belum ada manajemennya.

b. Tingkat kemampuan atau Capability Level domain TIPO05 Mengelola Program dan Project berada pada level 1 yaitu performed process. Hasil tersebut menunjukan bahwa proses yang terimplementasi telah mencapai tujuan prosesnya, dilakukan tetapi belum ada manajemennya.

c. Tingkat kemampuan atau Capability Level domain TIPO07 Mengelola operasi berada pada level 1 yaitu performed process. Hasil tersebut menunjukan bahwa proses yang terimplementasi telah mencapai tujuan prosesnya, dilakukan tetapi belum ada manajemennya.

3. Pemetaan framework SIMCOBIT lebih simple untuk melakukan evaluasi khusuny untuk organisasi yang berada di Indonesia.

\section{Saran}

Setelah mengetahui hasil evaluasi yang menyatakan bahwa penerapan tata kelola Teknologi Informasi pada STIK Bina Husada Palembang berada pada level 1 untuk proses TIPO01, TIPO05 dan TIPO07,Organisasi ingin meningkatkan nilai Capability Level menjadi naik 1 level dari hasil yang telah dicapai saat ini pada kedua prosesnya. Untuk mencapai nilai Capability Level yang diinginkan, maka diberikan rekomendasi sebagai berikut:

a. Capability Level domain TIPO01 adalah level 1, sedangkan Capability Level yang ingin dicapai adalah level 2, dengan hasil analisis gap bernilai 1 . Untuk mencapai nilai Capability Level yang diinginkan, maka diperlukan pembentukan suatu bagian khusus yang tepisah dari bagian LPPM-PT dan memiliki job descripton dan Standar Operational Procedure yang terdokumentasi dimana dokumen tersebut berisi suatu rangkaian prosedur terpadu, kebijakan-kebijakan, panduan penggunaan setiap sistem informasi dalam mengelola Teknologi Informasi, menjalankan teknologi dan proses bisnis yang aman serta sejalan dengan organisasi

b. Capability Level domain TIPO05 adalah level 1, sedangkan Capability Level yang ingin dicapai adalah level 2, dengan hasil analisis gap bernilai 1 . Untuk mencapai nilai Capability Level yang diinginkan, maka diperlukan pembuat standar untuk pengelolaan program dan proyek terkait kebutuhan, risiko, biaya, jadwal dan mutu terkait pengembangan program dan proyek yang selaras dengan Organisasi STIK Bina Husada Palembang.

c. Capability Level domain TIPO07 adalah level 1, sedangkan Capability Level yang ingin dicapai adalah level 2, dengan hasil analisis gap bernilai 1 . Untuk mencapai nilai Capability Level yang diinginkan, maka diperlukan pembuatan dokumen kebijakan pencegahan perangkat lunak dari berbagai bahaya sebagai perlindungan dari penyalahgunaan Teknologi dan Sistem Informasi. Selain itu juga diharapkan dibuat dokumen tertulis yang berisi pembahasan pembagian hak akses pengguna sesuai dengan kebutuhan unit bisnisnya, serta SOP yang mendefinisikan, mengatur dan memberikan pedoman kegiatan dalam prosedur perlindungan sistem informasi dan teknologi dari penyalahgunaan prosedur penggunaan Teknologi Informasi

\section{Daftar Pustaka :}

Arikunto, S. 2006. Prosedur Penelitian. Jakarta: Rineka Cipta.

Arikunto, S., Jabar, A., \& Safrudin, C. 2008. Evaluasi Program Pendidikan. Jakarta: PT Bumi Aksara

Widya, C. 2017. SIMCobit Model IT Audit untuk Organisasi di Indonesia. Jakarta: Disertasi Pascasarjana Universitas Gunadarma.

Firmansyah, D. 2015. Pengukuran Kapabilitas Pengelolaan Sistem Informasi Sub Domain Deliver, Service,Support 01 Menggunakan Framework Cobit 5, Studi Kasus Politeknik Komputer Niaga LPKIA Bandung. Konferensi Nasional Sistem \& Informatika 2015. 
Governance Institute. 2000. Management Guidelines COBIT 3rd Edition. HYPERLINK "http://www.isaca.org" http://www.isaca.org

Grembergen, W. V. 2004. Strategies for Information Technology Governance. Idea Group Publishing.

Handoko, T. H. 2003. Manajemen: Cetakan Kedelapanbelas. BPFE: Yogyakarta.

Ignatius A. M. 2010. Audit Sistem Informasi Perpustakaan STIKOM Surabaya menggunakan standar COBIT, SNASTI 2010, OSIT 49 Surabaya.

ISACA. 2012. COBIT 5 Enabling Processes. Rolling Meadows: ISACA. ISO / IEC 15504-2:2003

Peterson, R. R. 2003. Configurations and Coordinaton for Global Information Governance: Complex Designs in A Transtional European Context. Proceedings of the 34th HICSS Conference.

Putri, R. E. 2016. Penilaian Kapabilitas Proses Tata Kelola TI Berdasarkan Proses DSS01 Pada Framework COBIT 5. Jurnal Corel IT, 2, (1).

Endang, S., Mulyani, S., \& Suyetty. 2015. Pengantar Administrasi Perkantoran Bidang Keahlian Bisnis dan Manajemen untuk SMK dan MAK Kelas XI. Jakarta: Erlangga.

Sugiyono. 2010. Metode Penelitian Kuantitatif, Kualitatif dan $R \& D$. Jakarta: Alfabet.

Utomo, A. P., \& Mariana, N. 2011. Analisis Tata Kelola Teknologi Informasi (IT Governance) pada Bidang Akademik dengan COBIT Framework Studi Kasus pada Universitas Stkubank Semarang. Jurnal Teknologi Informasi DINAMIK, 16 (2), .

Weber, R. 1999. Information System Control and Audit. Prentice Hall. TheUniversity Queensland.

Weill, P., \& Vitale, M. 2002. What IT Infrastuctural capabilities are needed to implement e-business models. MIS Quarterly Executive, 1(1), 17-34. 